\title{
UN PROBLEMA DE VIGENCIA Y APLICACION NORMATIVA: LA NUEVA LEY DEL SUELO
}

\author{
$711.14: 347.2(46)$
}

$$
\text { por }
$$

\section{Carlos Carrasco Canals}

SUMARIO: I. INTRODUCCION.-II. SISTEMA DE DEROGACION DE LA LEY 19/1975, DE 2 DE MAYO.-III. MODIFICACION, DEROGACION Y ADICION A LA LEY DEL SUELO DE 1956. - IV. DOS PREAMBULOS, DOS ARTICULOS PRIMEROS, DUPLICIDAD SORPRENDENTE.-V. LEGISLACION DELEGADA Y LEY DEL SUELO.-VI. EL PROBLEMA DE LA VIGENCIA Y APLICACION EN EL CONTEXTO INTERNO DE LA NUEVA LEY DEL SUELO.-VII. UN GRAFICO DE LA SITUACION: DEDUCCIONES DE GRAFICAR LA VIGENCIA DE LA NUEVA LEY DEL SUELO.

\section{INTRODUCCION}

La aplicación del ordenamiento jurídico plantea singulares situaciones, de las que nos hemos ocupado en ocasiones (1), si bien referida a normas de carácter histórico, pero hitos importantes en su día y consideradas hoy monumentos jurídicos, en razón de la

(1) Vid. nuestro trabajo monográfico: «Teoría y realidad administrativa. Un ejemplo de aplicación del ordenamiento: el Real Decreto de 18 de junio de 1852 (Bravo Murillo)», en Información Juridica, Revista del Ministerio de Justicia, números $315,316,317$ y 318 , años $1972-73$, donde en el número 315 , parte primera, en la introducción se estudia con caracteres de generalidad la aplicación del ordenamiento jurídico; como consecuencia de su creación, el hallazgo de la norma, su validez y eficacia son objeto también de análisis. Vid. págs. 92 y sigs. de la citada revista. 
importancia de la materia regulada, el momento en que se produjeron y la novedad, incluso audacia, en la normación.

El tema de la ordenación urbana, el régimen del suelo, es hoy prioritario, sensibiliza socialmente y supone un impacto importante, más aún ante un nuevo régimen jurídico, como el recientemente aprobado.

La Ley 19/1975, de 2 de mayo, publicada el día 5, de reforma de la Ley sobre Régimen del suelo y Ordenación urbana, plantea una curiosa problemática en relación con su vigencia. Tema interesante, que despierta toda serie de inquietudes polémicas, sobre el que se reflexiona, discute e incluso se coloquia (2).

Los iniciados en esta temática aparentemente no reparan en las cuestiones suscitadas, pues por costumbre, inercia o ejercicio son expertos, experimentados y el tema les preocupa cuando de él se ocupan, pero con resortes suficientes siempre para salir dignamente airosos ante las dificultades, gracias a su aludida experiencia: Su profesionalidad suple, como el celo castrense, la factible imposibilidad de aplicación, o superan escollos tal vez para otros insalvables.

No obstante, existe un sector, quizá el más importante, el de los afectados, administrados simples, no cualificados, que se encuentra perplejo ante la nueva normativa. Por supuesto, los profesionales dedicados al urbanismo desde una perspectiva no jurídica enfocan, desde su óptica peculiar, el problema, y ante un nuevo estándar jurídico que les determina son conscientes y están preocupados en la actualidad.

Las afirmaciones anteriores justifican esta aportación por si es útil, al menos en el ánimo de clarificar cuestiones y establecer de alguna manera un orden, si bien problemático, que coopere a la seguridad que al Derecho debemos demandar.

La doctrina, hasta el momento, o no se ha ocupado del tema o si lo ha hecho la forma ha sido tangencial, sobre la validez, cara al

(2) Buen ejemplo de esta afirmación es el recientemente celebrado coloquio sobre aReforma de la Ley del Suelo», organizado por la Revista de Derecho Urbanistico en el Salón de Actos del Consejo Superior de Investigaciones Científicas los días 19 al 23 de mayo de 1975, en donde hemos podido detectar, sobre todo el pasado día 19, con la intervención de Jesús González Pérez, la inquietud existente entre los profesionales dedicados al urbanismo (juristas, economistas, arquitectos, sociólogos, urbanistas, etc.) en relación con la aplicación del nuevo régimen jurídico. 
futuro de la Ley, hoy reformada, de 1956 (3). Por supuesto, se ha comentado, adoptado posturas en razón a la oportunidad, conveniencia y coyuntura de un nuevo texto reformado que discipline el fenómeno urbanístico (4).

Tampoco es ahora el momento de enjuiciar, valorar o criticar la política urbanística llevada a cabo, o la evolución experimentada y los avatares de la Ley de 1956, se trata exclusivamente de un intento de clarificación frente a la creación de un ordenamiento nuevo de los problemas ya presumibles, los ya planteados, y sin intentar una futurología de despacho examinar el tema de la vigencia y de la aplicación de la nueva Ley del Suelo.

Las leyes entrarán en vigor a los veinte días de su completa publicación en el Boletín Oficial del Estado, si en ellas no se dispone otra cosa, dice el actual artículo $2 .^{\circ}$ del vigente Código civil, en su versión modificada por Ley 3/1973, de 17 de marzo, y Decreto $1.836 / 1974$, de 31 de mayo, Decreto legislativo que aprueba el nuevo texto articulado con la reforma del título preliminar del Código civil bajo la rúbrica ahora «de las normas jurídicas, su aplicación y eficacia».

La recientemente publicada Ley del Suelo no dice nada en relación con la vacatio legis, que deben soportar, en general, toda las normas. Período de interinidad, posterior a la publicación, después de la promulgación, donde la eficacia no aparece, siendo la norma plenamente válida, pero transitoriamente ineficaz, es, como se ha dicho, de veinte días naturales, pues el cómputo de plazos y señalamiento de téminos funciona de manera distinta que en el Derecho administrativo disciplinado por la Ley de Procedimiento administrativo, y en este supuesto se rige, respecto a la aplicación general de las normas jurídicas, por el Código civil (5). Al no alu-

(3) Tomás Ramón Fernandez Rodrfguez: «El urbanismo concertado y la Ley del Suelo», Cuadernos de Administración Pública, núm. 2, I. E. A., Madrid, 1974, aparecido y distribuido en el presente año; trabajo premiado en 1973 con el Primer Premio de Investigación Fernando Albi, vid. págs. 22 y sigs. Sobre las características de la Ley del Suelo de 1956, vid. E. Garcfa de ENTERrfa: aLa Ley del Suelo y el futuro del urbanismo», en Problemas actuales de Régimen local, Sevilla, 1958.

(4) Vid. el último número de la Revista de Derecho Urbanistico, marzo-abril 1975, en especial el artículo de José Luis GonzÁlez-Berenguer: ante una nueva Ley del Suelo», págs. 13 y sigs.; el autor no se muestra precisamente partidario del nuevo texto reformado y examina los que estima errores en la nueva redacción; no se plantea el objeto de este trabajo sobre la vigencia.

(5) El artículo 5.2 del Código civil vigente dice: «En el cómputo civil de los plazos no se excluyen los días inhábiles». 
dirse a plazo de vigencia, como hacía la anterior Ley del Suelo (6), el actual texto legal reformado entra en vigor el 25 de mayo de 1975.

Parece sencillo, claro y contundente, pues, y si no hay tema tampoco problema, en relación con la vigencia de la nueva Ley, pero si reflexionamos es evidente que existe una posible hipótesis problemática.

El trabajo de la búsqueda de la norma aplicable nos conduce al de la validez y eficacia y, a su vez, como en un proceso y concatenación, al de la derogación, si no se regula ex novo una materia, como en este supuesto. Situación aún más compleja, pues lo aprobado y promulgado no es sino un texto reformado que deroga, declara vigentes y crea ordenamiento con nuevos artículos.

\section{SISTEMA DE DEROGACION DE LA LEY 19/1975, DE 2 DE MAYO}

El actual texto reformador de la Ley de 12 de mayo de 1956 tiene unas especiales características cuya peculiaridad intentamos analizar desde la perspectiva de la derogación del régimen jurídico anterior.

Como es posible utilizar muy diversos sistemas de derogación, examinamos a continuación el elegido por la nueva Ley del Suelo.

La postura adoptada por la norma legal examinada es compleja, complejidad testimoniada por lo siguiente: la disposición final primera de la Ley de 2 de mayo de 1975 elige una fórmula al uso que necesita de una labor complementaria de interpretación, se dice: "quedan derogadas cuantas disposiciones se opongan a lo establecido en esta Ley». Este procedimiento, convenido y usual, obliga a conocer cuáles son aquellas normas que se oponen a lo determinado en el nuevo texto legal. Más aún, en virtud de lo dispuesto en la Ley de Procedimiento administrativo, hay obligación de publicar tablas de derogaciones y vigencias (7), exigencia cum-

(6) La Ley sobre Régimen del suelo y Ordenación urbana de 12 de mayo de 1956, publicada el 14 de mayo de 1956, disponía la entrada en vigor de dicha Ley -a los sesenta días de su publicación en el Boletín Oficial del Estados (disposición final primera).

(7) El artículo 129.3 de la Ley de Procedimiento administrativo de 17 de julio de 1958 establece, respecto de los anteproyectos de ley y cualquier disposición de carácter general, la necesidad de acompañar una tabla de vigencias, y se deben 
plida por reenvío a la publicación del texto refundido de la Ley del Suelo.

Pero a continuación de declarar de forma general la derogación por vía excepcional aparece una fisura, pues se dice: «con las salvedades que se contienen en las disposiciones siguientes"; como las siguientes son disposiciones finales y transitorias, se entiende dichas disposiciones contienen y exceptúan el régimen normal derogatorio. El examen de tales disposiciones, realizado más adelante, nos ofrece un panorama multicolor, a veces intrincado, que es necesario mostrar para poder actuar con un margen de seguridad en un futuro, ya presente en muchos aspectos. El análisis de la situación descrita nos da una unidad de medida, el metro utilizado para realizar esta labor importante, para poder afirmar con seguridad la realidad legislativa vigente al respecto, en la materia de ordenación urbana y régimen del suelo.

Ahora bien, la nueva Ley, en el campo de la derogación, no se limita a lo enunciado, participa también del sistema de declarar en suspenso las normas anteriores relacionadas con su contenido hasta un momento posterior en el plazo de un año, es decir, hasta el 5 de mayo de 1976. Esto no se hace de forma expresa y clara, pero se deduce que hasta no contar con una tabla de vigencias y derogaciones sería atrevido realizar esta labor si se promete legalmente ha de hacerse. De alguna manera algunos aspectos tendrán esta suspensión interina, expectante, pues aplicar normas afectadas por contagio o por rechace no congruentes, aunque vigentes, por falta de derogación, sería una verdadera osadía. Hay, pues, un sector, una faceta normativa declarada vigente, pero suspendida de alguna manera su aplicación, pues les falta una congruencia necesaria con el nuevo texto. Por vía de interpretación no podemos declararlas derogadas, pues no hay una contradicción, pero no se pueden aplicar al faltarles esa correspondencia necesaria y obligada con el nuevo texto; como muestra simple se puede aludir a los cinco primeros artículos de la Ley de 1956, declarados vigentes, pero en cierta manera suspendidos; es evidente que ya no hay Plan Nacional de Urbanismo (es Plan Nacional de Ordena-

consignar expresamente las normas anteriores que han de quedar total o parcialmente derogadas. La nueva Ley del Suelo remite al texto refundido esta obligación en el inciso último de la disposición final segunda al decir: edeberá incluir la tabla de vigencias de disposiciones anteriores sobre la misma materia y consignará expresamente las anteriores que han de quedar total o parcialmente derogadas». 
ción), tampoco planes provinciales, comarcales y municipales (sino planes directores territoriales de coordinación, planes generales municipales y normas complementarias y subsidiarias de planeamiento).

El proceso de derogación complejo de la nueva Ley del Suelo continúa participando de todos los posibles sistemas más usuales para realizar este cometido. También, en definitiva, se establece que normas anteriores continúen aplicándose mientras se publica la norma correspondiente de la nueva Ley. Aquí se plantea un fenómeno singular, la Ley del Suelo de 1956 no preveía unả réglamentación general, un reglamento ejecutivo, aunque naturalmente se autorizaba al Ministerio de la Gobernación (después sería Vivienda), no al Gobierno, para dictar disposiciones complementarias para la ejecución de la Ley (8); sin embargo, la nueva Ley prevé, con mandato imperativo, en un plazo de seis meses desde la publicación del texto refundido, dictar por el Gobierno, mediante Decreto, un reglamento general, o en su caso los reglamentos parciales que estime oportunos, para el desarrollo y aplicación de la nueva Ley (9). La derogación de una Ley no supone, sin más, la de sus reglamentos, sean ejecutivos, independientes o delegados. La anterior Ley supone la base para una serie de disposiciones complementarias del más diverso rango, con ropaje jurídico de Ley (de zonas verdes de 2 de diciembre de 1963, de valoración de terrenos sujetos a expropiación en ejecución de planes de vivienda y urbanismo, Ley de 21 de julio de 1962; las Leyes de Ordenación urbana de grandes ciudades, la del Area Metropolitana de Madrid, etcétera), de Decreto (todas las de valoración y expropiación de terrenos, enajenación y cesión de parcelas y solares o para evitar construcciones clandestinas, por citar algunos de los muchos supuestos), por Orden ministerial (caso harto frecuente, pues las normas anteriores han sido desarrolladas mediante este tipo de manifestación de la facultad normativa del Ejecutivo) e

(8) La disposición final cuarta de la Ley de 12 de mayo de 1956 dice: aEl Ministerio de la Gobernación dictará las demás disposiciones complementarias precisas para la ejecución de esta Ley».

(9) La disposición final décima de la Ley de 2 de mayo de 1975 dice: «El Gobierno, en los seis meses siguientes a la aprobación del texto refundido de la Ley de Régimen del suelo y Ordenación urbana, dictará por Decreto, a propuesta del Ministerio de la Vivienda, previo dictamen del Consejo de Estado, el reglamento general $o$, en su caso, los reglamentos parciales que estime oportunos para el desarrollo y aplicación de esta Ley». Parece que la obligación no es opcional, hay que dictar un reglamento general $y$, si es necesario, además reglamentos parciales, si se consideran imprescindibles, respecto a determinados aspectos. 
incluso por disposiciones de inferior rango (resoluciones, instrucciones, etc.). Hasta cumplirse las previsiones de las disposiciones finales y transitorias en el nuevo cuerpo legal pervive una serie de disposiciones, consecuencia de la anterior normativa. Claro es que en este caso concreto el asunto se complica aún más, el texto ha sido reformado, pero en un caso hipotético $i s i$ derogado un artículo o varios que condujeron a su desarrollo en otras normas, se entienden derogadas éstas? (10). La solución es que no, para evitar que se produzcan las más diversas lagunas en el ordenamiento.

Como la nueva Ley es prolija en cuestiones y participa fragmentariamente de cualquier sistema o técnica imaginable en materia de derogación (11), el sistema llamado de incrustación lo practica, pero con una potenciación, con un voltaje e intensidad típico. Un simple recuento del texto de la Ley antigua, de 1956, nos ofrece 228 artículos, 4 disposiciones finales y 12 disposiciones transitorias. El texto legal nuevo, de 1975, contiene 18 artículos derogados y no sustituidos, 103 artículos nuevos que sustituyen a los correspondientes antiguos, algunos en ocasiones con un artículo bis y ter, y 111 artículos que permanecen. Se han contabilizado algunos bis considerados como nuevos, en total sólo en cuatro ocasiones, por lo que el número total sufre un aumento de 228 a 232, que suman los tres tipos de artículos enunciados. No obstante, la incrustación no se para aquí; si observamos la disposición transitoria quinta, determinados artículos (12), ahora sin efecto, serían sustituidos cuando entre en vigor la Ley de Bases del Estatuto de Régimen local. Es necesaria una pausa para aclarar esta situación, que el legislador tal vez no ha meditado lo suficiente en relación con el futuro, y las posibles consecuencias pre-

(10) José Antonio Garcfa-Trevijano Fos: Tratado de Derecho administrativo, tomo I, 3." edición, revisada y ampliada, Madrid, 1974, Editorial Revista de Derecho Privado, al examinar la derogación de la norma, vid. págs. 333 y sigs., mantiene la teoría de que la derogación de una ley no supone la de las disposiciones complementarias de la misma (pág. 334).

(11) Sobre el sistema de derogación por incrustación, criterio utilizado, vid. Garcfa-Trevijano, op. cit., pág. 335, donde se examina y ejemplifican algunos supuestos en que se han llevado a cabo las modificaciones parciales de leyes con este sistema.

(12) Los artículos 162 a 164 y 183 a 188, inclusives, de la Ley del Suelo de 12 de mayo de 1956 quedarán derogados y se entenderán sustituidos por los preceptos de la Ley de Régimen local, al tiempo que los nuevos 188 bis y 188 ter entrarán en vigor simultáneamente a la vigencia de la Ley de Bases del Estatuto de Régimen local (disposición final quinta). El preciosismo intelectual se ha disparado, y en su día aventuramos muy serias complicaciones, en cuanto al momento y modo de realizar estas previsiones. 
sumibles. No se sabe si intencionadamente, se ha producido una auténtica dinámica interna, con previsión de futuribles, en que un automatismo previsto parece va a funcionar, pero realmente puede plantear problemas importantes con esta incrustación de normas de segundo grado, no por menos importantes, sino por producirse en un tiempo futuro, nadie sabe cuándo, pero sí se puede adivinar la carga problemática y compleja planteada.

La cuestión está mimetizada, pero en realidad clara. La Ley de Bases del Estatuto de Régimen local se está discutiendo, hipotéticamente podría no aprobarse; si desechamos esta hipótesis, que plantearía un problema de imposibilidad, el día en que se apruebe la Ley de Bases del Estatuto de Régimen local empezarán a funcionar las previsiones de la disposición final quinta. Pero, atención, se sugieren las siguientes circunstancias:

a) Derogación automática de nueve artículos, 162 a 164 y 183 a 188, ¿cuándo?, a la entrada en vigor, se nos dice, de la Ley de Bases; la cuestión es palmaria y no hay duda. Sin embargo, hay una imposibilidad metafísica, ontológica, de incorporar bases a una ley formalmente articulada, que probablemente se encuentra ya con un contexto refundido en virtud del imperativo de ofrecerse éste antes del 5 de mayo de 1976. Pero si no hay texto refundido la incrustación se hace en el texto de 1956; estamos en presencia de unos preceptos vigentes con interinidad, condenados a su derogación, sustituidos por normas no articuladas y situados en la parte del cuerpo legal no reformado transitoriamente.

Para ser congruente, la sustitución debería esperar al texto articulado de la Ley, Estatuto de Régimen local, pero esta interpretación es muy generosa con la gramatical y evidente, además de no resolver la cuestión, sino dilatarla.

b) Toda la problemática, incidencias, modificaciones y trances que necesariamente ha de padecer hasta su promulgación la Ley de Bases del Estatuto de Régimen local se trasladan, parcialmente, en esos artículos citados, a la Ley del Suelo de 1956 en sus artículos no afectados, pero con expectativa de serlo. Esto entraña otra cuestión, y es ¿puede entenderse en puridad texto refundido con esta cuestión pendiente si llega el momento de su aprobación y todavía el Régimen local no cuenta con la consagración legislativa? La sustitución de preceptos no va a ser fácil, significamos esta evidencia. 
c) Los artículos 188 bis y ter entran en vigor en el momento simultáneo al de la Ley de Bases del Estatuto de Régimen local. La posible dificultad parece aparente $y$, sin embargo, es real. Lo dicho en los dos apartados anteriores se aplica también a este supuesto, pero se añaden más circunstancias. Estos dos artículos curiosamente son válidos pero ineficaces en una situación jurídica pendiente. Supuesto nuevo en nuestra legislación, la vacatio no depende ya del transcurso de un tiempo presumible, fijado, anticipado, pende de la eficacia por puesta en vigor de otra norma, que puede incidir y de hecho lo hace de forma decisiva.

No analizamos la importancia de las disposiciones contenidas en las normas de esta manera implicadas, se enuncia la complejidad y consecuencias, como ratio la posible incongruencia, pues o el legislador ha adivinado lo previsible al legislar sobre el suelo o desconoce el futuro y nos ofrece un avatar de insospechadas consecuencias.

d) La labor integradora que caracteriza a un texto refundido se encuentra evidentemente mediatizada, en primer lugar porque si quiere actuar el Gobierno en puridad deberá esperar a la aprobación del Estatuto de Régimen local para incrustar normas redactadas como Bases, con el posible rechazo enunciado por vía de congruencia; dar eficacia a los artículos repetidos y citados, o incorporarlos con validez pero ineficaces. El tema se complica si tenemos en cuenta otras incidencias tangenciales, en lista de espera, para incorporarse al texto refundido, como las de la disposición final cuarta de la nueva Ley del Suelo (13). En definitiva, parece que el texto refundido sería en cierta manera provisional si cumple en tiempo y formalidades las exigidas y estará pendiente de condicionamientos durante un período, en este momento totalmente imprevisible. De alguna forma esto atenta contra la seguridad, y se quiera o no el Derecho persigue un fin de pacífica convi-

(13) $\alpha$ El Consejo de Ministros, en el plazo de' seis meses, a contar desde la publicación del texto articulado de la Ley de Régimen local, a propuesta de los Ministros de la Gobernación y Vivienda y previo dictamen del Consejo de Estado, incorporará al texto refundido de la Ley del Suelo, en lo que fuera necesario, las competencias urbanísticas de las Entidades locales en la forma y ámbito que para cada una de ellas establezca la legislación de Régimen local». Prueba evidente que ahora con un plazo más dilatado, adespués del texto articulado de la Ley de Régimen locals, todavía hay cuestiones pendientes; luego el texto refundido no integra el total de la refundición, pues se prevé padezca aún incorporaciones y seguirá un tiempo de provisionalidad, pues necesita aún de algunos añadidos, congruencias, adaptaciones, revisiones, etc. 
vencia, y en materia tan trascendental y con efectos sociales tan acusados, la seguridad es de gran importancia. Naturalmente, esta situación no es imputable a nadie y sólo consecuencia del momento en que la coyuntura ha determinado por coincidencia una serie de reformas producidas casi simultáneamente, donde se debía haber organizado el orden de prelación en pro de la aludida seguridad jurídica.

e) .El solapamiento producido entre Ley del Suelo y Ley de Bases del Estatuto de Régimen local, alcanzando la nueva Ley del Suelo su aprobación antes de la Ley de Régimen local, con las consiguientes e íntimas relaciones y conexiones, no es el tema ahora sometido a análisis, pero parcialmente se hace patente y es como un hálito, un espíritu, casi fantasmagórico siempre presente, aunque no sea invocado, si bien en esta ocasión se le ha convocado de forma expresa por el propio legislador del suelo. El tema merece un tratamiento y actuación puntual sobre él. No obstante, a efectos de vigencia, eficacia, validez, en definitiva aplicación de la ordenación del suelo, es obligada la referencia.

En resumen, se han enunciado los aspectos más importantes en el complejo sistema arbitrado para la derogación y puesta en vigor de un novedoso régimen del suelo y ordenación urbana. El criterio utilizado ha sido descrito en grandes líneas: su objetivo era clarificar aspectos con una llamada de alerta a posibles situaciones previsiblemente dadas, cuando las circunstancias se produzcan y el factor tiempo opere, pues ésta es otra característica de la nueva Ley, tal vez con mayor énfasis que en otros supuestos; las improntas del tiempo funcionan radicalizando la temática por imperativos, con otros eventos normativos y haciendo perentoria la toma de decisiones, tarea encomendada desde ahora al Gobierno; con ánimo de cooperación aportamos estas insinuaciones en evitación de situaciones, urgencias y posibles imprevisiones.

Descritas de forma general las técnicas empleadas y aventuradas las posibles complicaciones, posiblemente producidas como consecuencia, se debe afrontar ahora, desde la perspectiva legal recientemente aprobada, cuál ha sido la forma empleada para llegar a esta situación. 


\section{MODIFICACION, DEROGACION Y ADICION A LA LEY DEL SUELO DE 1956}

La nueva Ley sobre Régimen del suelo y Ordenación urbana, en su artículo primero, establece que respecto de las denominaciones de títulos, capítulos y secciones de la anterior Ley de 1956 y de los artículos de la misma, tal como se indica, han quedado «modificados, derogados o adicionados» en los términos que en la misma se determinan.

Cierto, como hemos visto y se examina más adelante, no sólo hay modificaciones, derogaciones y adiciones, pero es momento de examinar dichas rúbricas de actuación, referidas al articulado y denominaciones indicadas.

La modificación supone el cambio de algo, filosóficamente dar un nuevo modo de existir a la sustancia. Jurídicamente hay cambio y permanencia, el precepto no se deroga, no se sustituye tampoco por otro, ni desaparece ni se completa por adición. Hay un impacto que supone afectación, cambiando su contenido, significado, imperativo distinto sobre la base de otro anteriormente existente.

La derogación es una anulación, supone una expresa declaración de que algo desaparece, existe una acción de abolición de una norma establecida.

La adición, nombre prístino de la suma, supone agregar algo, añadir, se incorpora a manera de suplemento o complemento algo al texto anterior, se puntualiza, se matiza, conservando lo dicho anteriormnte. Evidentemente, adicionar representa una modificación como consecuencia; en sentido puro entendemos por adición no la técnica de artículos bis o ter, sino cuando permaneciendo el texto anterior se ha adicionado algo nuevo no ha habido cambio en el texto, eso sería modificación, se ha producido una agregación simplemente; como consecuencia habrá modificación, pero no en su propia estructura, sino en el conjunto total de la norma, respecto a los obligados.

Contemplemos ahora esta tría de actividades en relación con los títulos, capítulos y secciones, así como respecto del articulado.

Actividad en relación con los títulos, capítulos y secciones de la Ley del Suelo de 1956.

Los títulos de la reformada Ley del Suelo, uno preliminar y siete títulos más, no han sufrido otra alteración, en relación con los 
tres tipos de actividades citadas, que la del título primero por adición, actualmente "planeamiento urbanístico del territorio» frente al epígrafe de "planeamiento urbanístico» anterior.

Los capítulos a veces se modifican; el capítulo tercero del título tercero, en vez de "formas de gestión», se cambia por el de "sistema de compensación"; se derogan, como en el caso del capítulo segundo del título tercero, o por último se adicionan, es el supuesto también del capítulo segundo del título tercero, ahora «de los sistemas de actuación", epigrafiando en otro lugar, a partir del artículo 106, en vez desde el 103, como en la Ley de 1956.

Sorprende que se deroguen epígrafes, que a modo de rúbrica titulan una división; la técnica no es correcta y se debían haber simplemente suprimido un capítulo, un título, una sección, que, en definitiva, son rúbricas y no normas, y sólo las normas de cualquier naturaleza son susceptibles de la actividad de derogación.

En cuanto a las secciones, con frecuencia se derogan, ante dicha actitud argumentamos como en el anterior supuesto. Ejemplos numerosos pueden observarse de secciones derogadas en su epígrafe, por ejemplo las secciones primera y segunda del título primero de la Ley.

Veamos a continuación cómo se modifican, derogan y adicionan artículos en la nueva Ley del Suelo.

La modificación es tarea habitual y 103 artículos, sensiblemente la mitad del texto de 1956, han sido modificados.

La derogación de artículos, sin sustitución, sólo se ha producido respecto a 18 (artículos 46,101,124, etc.), y estos artículos desaparecen.

En relación con la adición, se plantean algunas cuestiones. Esta actividad se ha desarrollado en puridad respecto de la distribución esquemática en títulos, capítulos y secciones, pero no propiamente en artículos. No aparece ningún artículo adicionado simplemente en el nuevo texto legal del suelo. Sólo en cuatro casos, los de los artículos 45, 58, 86 y quizá el 223 se puede mantener, se ha realizado esta tarea, pero con la salvedad de que hay también pequeñas modificaciones, cambio de palabras o expresiones, añadiéndose una auténtica adición (por ejemplo, en el artículo 45 ahora se dice aprobación por formación; en el artículo 58 Municipios por poblaciones; y en el 86 la expresión a efectos urbanísticos se cambia por la de a efectos de esta Ley y además se altera también la estructura del mismo; también en el artículo 223 ocurre un caso similar). 
Sorprende que el único caso de precepto reformado en que se mantiene el texto antiguo es el del artículo 99, por supuesto, además de aquellos no citados y reproducidos en los que se da por entendido permanecen como se encontraban. El artículo 99, sin embargo, sufre alteración, pero no por adición, sino por sustracción. En su primera versión tenía cuatro apartados, y con la nueva regulación del suelo de 1975 se reducen a tres, desapareciendo el último. De esta manera de hacer, aunque sea ejemplar y única, no nos habla el artículo $1 .^{\circ}$ de la nueva Ley.

Somera, casi estadísticamente, con intención descriptiva, sin ánimo exhaustivo, se ha ofrecido fotográfica y panorámicamente en qué ha consistido esta triple actividad de modificación, derogación y adición, que acota en cierta manera, pero no agota la realidad ni lo realmente realizado en relación con la eficacia, puesta en vigor, en este nuevo régimen jurídico del suelo y ordenación urbana.

\section{DOS PREAMBULOS, DOS ARTICULOS PRIMEROS, DUPLICIDAD SORPRENDENTE}

Sumariamente, la nueva Ley del Suelo, en su sistema de derogaciones o a través de las actividades realizadas para ofrecer un texto reformado, nos ha ido sorprendiendo. En primer lugar, pues no sólo hace lo que dice, amodificar, derogar y adicionar», sino que, en general, no adiciona $y$, sin embargo, restringe, amén de otras actividades, que posibilitan un texto como el estudiado.

En la actualidad nos encontramos con dos leyes que, respectivamente, tienen dos preámbulos a manera de introducción, cada uno el suyo, y dos artículos primero. Si se considera que los preámbulos de las disposiciones constituyen fuente de interpretacion auténtica de los preceptos (14), en la actualidad nos encontramos con dos interpretaciones legales en vigor. No se declara de forma expresa la derogación del preámbulo de la Ley de 1956, se elabora, como es común en todas las disposiciones con rango de ley, una exposición de motivos, con nueve apartados, pórtico de la nueva Ley de 1975; el anterior tenía ocho apartados. Se promete en el

(14) Reiterada jurisprudencia del Tribunal Supremo asi to ha establecido. Vid. sentencias del Tribunal Supremo de 20 de mayo de 1950 y de 4 de noviembre de 1957. 
plazo de un año el texto refundido, ¿deberá también refundir los preámbulos? ¿El Decreto legislativo que aprueba el texto refundido tendrá un tercer preámbulo? ¿Se reproducirá el último de la Ley de 1975 ?

La técnica normal, en cuanto a textos refundidos, nos puede aclarar lo que es corriente hacer $y$, por vía de indicio, intuir lo posible a realizar.

Un caso típico de texto refundido lo constituye la vigente Ley de Régimen jurídico de la Administración del Estado. Existían dos normas en un principio: el Decreto-ley de 25 de febrero de 1957 sobre reorganización de la Administración Central del Estado (15). La Ley de 20 de julio de 1957 sobre Régimen jurídico de la Administración del Estado (16). Una disposición final (la segunda) prevé el texto refundido; singularmente esta autorización no fija plazo alguno para que el Gobierno realice esta tarea, que lógicamente debería estar en aquellos momentos a punto de finalizar, pues por Decreto de 26 de julio de 1957 se aprueba el texto refundido de la Ley de Régimen jurídico de la Administración del Estado (17). Por último, una Orden de la Presidencia del Gobierno de 9 de octubre de 1957 (18) dispone que cualquier referencia a la Ley de Régimen jurídico de la Administración del Estado debe hacerse al texto refundido y no al Decreto-ley de 25 de febrero de 1957 o a la Ley de 20 de julio de 1957, que además provoca la confusión de denominarse exactamente igual.

A nuestros efectos interesa saber qué ocurre con los preámbulos de las dos normas con rango de ley que se refunden. En este supuesto, la exposición de motivos que aprueba el texto refundido lo constituyen los cuatro apartados del Decreto-ley de 25 de febrero de 1957, y lo único que se hace con el preámbulo de la Ley de 20 de julio de 1957 es epigrafiarlo en otros cuatro apartados, consevando literalmente cuanto se decía. La única modificación, pues, es llamar aexposición de motivos» a esta parte no dispositiva del texto refundido y poner epígrafes a párrafos que se agrupan, conservando redacción y sintaxis.

(15) Norma publicada en el Boletin Oficial del Estado de 26 de febrero de 1957, la exposición de motivos tiene cuatro apartados.

(16) Publicada en el Boletin Oficial del Estado de 22 de julio de 1957, no tiene exposición de motivos, así titulada, sino preámbulo introductorio.

(17) Boletin Oficial del Estado de 31 de julio de 1957, con exposición de motivos, clasificada en ocho apartados y una parte dispositiva. El Decreto tiene una pequeña introducción y un artículo único de aprobación del texto.

(18) Boletín Oficial del Estado de 12 de octubre. 
La pregunta inmediata es si será posible conjugar en el futuro texto refundido los dos preámbulos actualmente existentes. Se puede entender que el de 1956 está derogado por el de 1975, degradado al menos en extensión o que permanece con toda intensidad, todo ello interinamente y sin arriesgar adivinaciones en relación con la postura adoptada por el Gobierno al proponer un nuevo texto refundido, probablemente con dos partes: una de exposición y otra dispositiva.

La hipótesis de derogación del preámbulo está avalada por las características de la nueva Ley, hay un articulado y divisiones que se cambian, sustituyendo el anterior por un nuevo texto. Pero esto se dice expresamente en relación con la parte dispositiva, no respecto de la introductoria.

Una interpretación sobre la hipótesis de una labor integradora y congruente es considerar el preámbulo de 1956, válido para los artículos del texto que no varían en 1975; naturalmente, todo lo referido a artículos derogados, añadidos, suplidos, etc., no es auténticamente interpretado por la exposición de 1956.

Por último, se puede considerar con plena validez el preámbulo de la reformada Ley de 1956 en toda su extensión, ya que no ha habido derogación expresa (19).

La exposición anterior puede calificarse de trivial si, como es de esperar, el texto refundido ofrece un preámbulo nuevo, que en definitiva y con las características de estas exposiciones previas será el vigente. No obstante, tiene importancia en el tiempo de interinidad, pues añade un elemento más de complejidad al tema desde el principio necesitado de clarificación: la aplicación de la norma como consecuencia de su vigencia.

Otro aspecto que sorprende es el de la existencia, por ahora, de dos artículos primero, el de la antigua y la nueva Ley.

La Ley del Suelo de 1975, cuando recoge un artículo con la misma numeración, le está modificando, completando o derogando por sustitución. Pero en este caso peculiar no se toca el antiguo título preliminar: "Finalidades y campo de aplicación de la Ley», luego se entiende vigente. Los cinco artículos que integran este título no han sido afectados. El artículo $1 .^{\circ}$ de la Ley de 12 de mayo

(19) La nueva redacción del Código civil establece en el artículo 2., 2: «Las leyes sólo se derogan por otras posteriores. La derogación tendrá el alcance que expresamente se disponga y se extenderá siempre a todo aquello que en la ley nueva, sobre la misma materia, sea incompatible con la anterior. Por simple derogación de una ley no recobran vigencia las que ésta hubiera derogadon. 
de 1956 delimita el objeto de la Ley. Cualquiera reconoce la importancia de los artículos iniciales en cualquier disposición legal (20); evidentemente, los artículos declarados intactos sufrirán un impacto interno; la redacción del texto refundido debe tener en cuenta en su labor de armonización y congruencia este supuesto (21). De ninguna manera, pues, puede entenderse derogado el artículo $10^{\circ}$ antiguo por el actual y vigente artículo $10^{\circ}$, pues no están en el mismo contexto ni se refieren a cuestiones idénticas, análogas, homogéneas, sino totalmente diferentes.

El tema de la vigencia, derogación, problemática, que se plantea entre el normativismo y el suelo no es actual, fue propuesto con sentido de anticipación hace años, después de 1956, con motivo de la primera Ley (22).

\section{LEGISLACION DELEGADA Y LEY DEL SUELO}

La nueva Ley plantea una serie de cuestiones que afectan a la vigencia de la misma a través del sistema relacionado para su desarrollo, texto refundido, incorporación de normas provinientes de otros regímenes jurídicos, etc.

En este aspecto sí que es prolífica la nueva ordenación del urbanismo y el régimen del suelo.

Se pretende simplemente enunciar el catálogo de cuestiones y, más que cuestionarse sobre las mismas, anunciar el momento en

(20) Alguna vez se ha dicho, y no sin gracejo, que las leyes deben empezarse a leer, en razón a su importancia, por los primeros artículos y que con una docena es suficiente; después ir a las disposiciones finales, derogatorias, transitorias, adicionales, etc., donde se encuentra toda la problemática de un cuerpo jurídico, como puede constituir el tratamiento legal del suelo.

(21) Esta labor de acomodación está prevista por el legislador de 1975 no sólo en relación con el texto de la Ley de 1956, reformada, sino incluso con otras disposiciones (vid. disposición final segunda, cuarta, sexta, etc.). Pero esta actividad es peligrosa y puede conllevar una extralimitación, el control y tutela del ejercicio de esta actividad es tema que supera por ahora nuestro cometido.

(22) José Antonio Garcta-TreviJano Fos: «Normativismo y Ley del Suelos, Anuario de Derecho Civil, Instituto Nacional de Estudios Juridicos, Madrid, 1960, separata, págs. 519-540. La cuestión, planteada con premonición y lucidez entonces, tiene actualmente una validez sorprendente. Desde las primeras líneas de este artículo se aclara el sentido de su título, se va a estudiar la vigencia de la Ley sobre Régimen del suelo y Ordenación urbana. Se relacionan la Ley del Suelo y el Reglamento de Solares, demostrando su derogación, para continuar con un planteamiento general de que hasta qué punto la Ley del Suelo, en su título cuarto, capítulo primero, sección primera, ha modificado la legislación anterior. Se concluye poniendo de manifiesto uno de los casos en que el normativismo es si no funesto, sí estéril o superfluo (pág. 538). 
que van a producirse las concurrencias en cada uno, las dificultades previsibles y en general plantear, sin ánimo dogmático, ese haz de posibilidades que nos muestra un aspecto rico en situaciones, y todas de alguna manera repercutiendo sobre la vigencia de la norma.

Un análisis de las 14 disposiciones finales nos arroja el siguiente resultado:

a) En el plazo de un año desde la publicación se debe aprobar por Decreto (legislativo) un texto refundido de la Ley de Régimen del suelo y Ordenación urbana (23).

b) El texto refundido está tasado, es decir, la labor de refundición se especifica a qué normas afecta y cómo debe conseguirse una armonización con los actuales preceptos de la Ley (24).

c) En todos los supuestos de delegación se autoriza al Gobierno, con excepción de un supuesto en el que el autorizado es el Consejo de Ministros, que en seis meses, desde la publicación del texto articulado de la Ley de Régimen local, incorporará al texto refundido de la Ley del Suelo las competencias urbanísticas de las Entidades locales (25).

d) Otra autorización al Gobierno es la de acomodar el texto refundido de la Contribución Territorial Urbana a los preceptos de la Ley del Suelo (26). En este supuesto sin plazo.

e) El Gobierno debe dictar las disposiciones necesarias (Decretos) para adecuar la clasificación del suelo y las limitaciones

(23) Disposición final segunda de la Ley de 2 de mayo de 1975 (apartado uno).

(24) Disposición final segunda, 2. Se han de integrar los artículos 11 del Decreto-ley de 25 de febrero de 1957 sobre reorganización de la Administración central del Estado; $13, b$ ), del Decreto $2.764 / 67$, de 27 de noviembre; 3. del Decreto 63/68, de 18 de enero; disposición final tercera del Decreto 2.994/72, de 13 de julio; la Ley $158 / 63$, de 2 de diciembre, sobre modificación de planes de ordenación y proyectos de urbanización, cuando afecten a zonas verdes y espacios libres previstos en los mismos.

(25) Supuesto contemplado en la disposición final cuarta, se trata de una refundición después del texto refundido aludido en nota anterior. Hay una aincor. poración» de un estándar, alo que fuere necesario», en relación con las compe. tencias urbanísticas otorgadas por la Ley del Suelo a las Entidades locales.

(26) Ahora se afecta otro texto refundido, el que aprueba la Contribución Territorial Urbana, aprobado por Decreto $1.251 / 66$, de 12 de mayo, que debe acomodarse a los preceptos de la nueva Ley del Suelo; con una observación se ha de tener especialmente en cuenta las repercusiones derivadas de las variaciones de calificación del suelo, determinadas por la aplicación de la nueva Ley, según se establece en la disposición final sexta, 1. Como no hay plazo para realizar esta tarea, si se hace pronto la adaptación será a la Ley de 2 de mayo de 1975, si pa. sado un año será el texto refundido. 
resultantes, para proteger el paisaje urbano y rural, en el momento de la valoración a efectos tributarios (27).

f) Otra autorización al Gobierno se refiere a que apruebe por Decreto legislativo un texto refundido de la Ley sobre Centros y Zonas de interés turístico nacional (28). En este supuesto se obliga a adaptar el texto refundido de la referida Ley a la nueva Ley del Suelo, pero con una limitación: alas normas de contenido urbanístico" son las que se adaptan, y de cualquier forma sigue vigente la Ley de Centros y Zonas de interés turístico nacional, en tanto no se apruebe el texto refundido. Se da el mismo plazo de refundición, pero no se dice desde cuándo ha de contarse ese plazo.

g) Se prevé un automatismo derogatorio al entrar en vigor la Ley de Bases del Estatuto de Régimen local, y los artículos 162 a 164 y 183 a 188 inclusives de la Ley del Suelo antigua se derogan y a continuación «se entienden» sustituidos por los correspondientes preceptos del Régimen local. Otros artículos aprobados, como son el 188 bis y ter, por excepción, no adquieren vigencia en el plazo de veinte días, como la Ley, sino que están a la expectativa de entrar en vigor la Ley de Bases del Estatuto de Régimen local (29).

h) Otro mandato imperativo al Gobierno, como en el supuesto del caso $e$ ), consiste en que debe fijar, a propuesta del Ministerio de la Vivienda, las condiciones y proporción en que se pueda adscribir a la construcción de viviendas de carácter social, la superficie edificable resultante de actuaciones públicas para la creación de suelo urbanizado, correspondiente al aprovechamiento (30). Por supuesto, falta el cuándo, no hay plazo previsto para cumplir la citada obligación.

(27) Esta previsión se contiene en el número 2 de la disposición final sexta, que alude al Gobierno para que dicte las disposiciones necesarias para el desarrollo de lo establecido en el artículo 47 bis. Tampoco se concede plazo alguno y es una obligación del Gobierno sine die frente al supuesto de la nota anterior, en que ese autorizan; aquí sí utiliza la fórmula coercitiva de eEl Gobierno... dictará...», lo que supone configurar el mandato como obligación.

(28) La Ley 197/1963, de 20 de diciembre, sobre Zonas y Centros de interés turístico, por otra Ley ajena, aunque próxima, se refunde; como no se tasa la materia será con toda la relativa al tema, pero adaptándola en sus normas de contenido urbanístico a la nueva Ley del Suelo, según se autoriza en la disposición final tercera.

(29) La disposición final quinta de la nueva Ley del Suelo establece este peculiar sistema que ha de crear algunos problemas, a los que ya hemos hecho alusión con anterioridad.

(30) Disposición final séptima, 3. Se dice textualmente: eEl Gobierno fijará, referido al aprovechamiento de los artículos 68.3 y 69.2 . 
i) En el plano de la posibilidad y coyunturalmente cuando las circunstancias lo aconsejen, el Gobierno podrá elevar las cuantías de las reservas y sólo disminuirlas excepcionalmente (31).

j) Como autorización se prevé que el Gobierno establezca los criterios con arreglo a los cuales los planes generales hayan de fijar la cuantía de las reservas y previsiones respecto del suelo urbano (32).

k) En orden a la organización, también se autoriza al Gobierno para que revise la composición de las Comisiones Provinciales de Urbanismo y, si las circunstancias lo aconsejan, modifique éstas y la de la Comisión Central de Urbanismo (33).

l) Otra autorización es la relativa a las adaptaciones de las cuantías de las multas, que puede realizar el Gobierno si evolucionan las circunstancias socioeconómicas, de acuerdo con el índice general ponderado de precios al por mayor del Instituto Nacional de Estadística (34).

il) Hay obligación, mandato al Gobierno, de dictar, mediante Decreto, en seis meses a partir de ser aprobado el texto refundido, el reglamento general, o en su caso reglamentos parciales, para el desarrollo y aplicación de la Ley (35). Esta previsión es nueva y obliga a tener un reglamento ejecutivo frente a la anterior Ley, en donde no se exigía tal obligación.

m) Se autoriza también al Gobierno para dictar las disposiciones precisas y adaptar, acomodando, la legislación hipotecaria a la nueva Ley del Suelo (36).

(31) Disposición final séptima, 1. Se refiere a reservas y previsiones de los artículos 9. ter, $1, b) ; 10,2, b), c), d)$ y $e$ ).

(32) Disposición final séptima, 2. Se prevé también la determinación directa de su cuantía con arreglo a las circunstancias urbanísticas de las poblaciones afectadas, lo cual es muy genérico.

(33) Disposición final octava. Parece que la revisión se impone y la modificación depende de las circunstancias. Respecto de la Comisión Central no hace falta aludir a que hipotéticamente no es reformable un organismo todavia inexistente.

(34) Disposición final novena. No es presumible, pero las multas establecidas en el artículo 215 bis, que son las aludidas, podrian hipotéticamente rebajarse si esos indices ponderados de precios bajasen, ya que la autorización es para la cadaptación» no para elevarlas simplemente.

(35) Sobre este tema, previsto en la disposición final décima, ya hemos hecho referencia. No está claro si la obligación es alternativa o si existe obligación de un reglamento general, y además, en su caso, parciales, que éstos pueden darse o no, pero no son incompatibles con el general.

(36) La disposición final decimotercera asi lo precisa con el fin de asegurar que las limitaciones y deberes establecidos en la Ley del Suelo, en los planes, programas, proyectos, normas, ordenanzas y catálogos se reflejen con toda exactitud en el Registro de la Propiedad. Tampoco en este supuesto se establece un plazo. 
n) Otro supuesto de autorización al Gobierno, éste para resolver el problema interino de la transitoriedad, es el caso de los Planes generales de ordenación vigentes en la actualidad, y hasta su adaptación a la nueva Ley, mediante Decreto, se puede acordar la aplicación de la nueva Ley del Suelo para programas de actuación urbanística a áreas o zonas que se determinen en el citado Decreto, cualquiera que sea la clasificación o uso urbanístico de los terrenos que comprendan (37).

n) Mediante la técnica imperativa de la obligatoriedad se determina también, en el plazo de un año, que el Gobierno elaborará y remitirá a las Cortes un Proyecto de Bases del Plan Nacional de Ordenación (38). El Plan, según la nueva Ley, debe contener las grandes directrices de ordenación del territorio, en coordinación con la planificación económica y social, para el mayor bienestar de la población (39). Se ha previsto la intervención de los organismos públicos y privados en su redacción; la aprobación por ley formal, la actualización y acuerdo con los Planes de Desarrollo Económico y Social se lleva a cabo por el Gobierno (40).

Esquemáticamente enunciadas las autorizaciones, obligaciones, perentoriedades del Gobierno y del Consejo de Ministros, Ministe-

ni incluso una obligación, existe una autorización simple para efectuar la referida acomodación.

(37) La disposición transitoria cuarta de la nueva Ley del Suelo, en su párrafo tercero, con la fórmula: a... el Gobierno, mediante Decreto, a propuesta del Ministro de la Vivienda, podrá acordar la aplicación de lo dispuesto en esta Ley para los programas de actuación urbanística en los supuestos regulados en el artículo 135...». La propuesta en este caso no es del órgano, Ministerio, sino de la persona que recubre el órgano, Ministro. Los supuestos regulados en el artículo 135 son aquellos programas de actuación que pueden formular y ejecutar directamente las Entidades locales y urbanísticas especiales sin necesidad de convocar un concurso. También de esta forma se pueden formular y ejecutar sin concurso programas que supongan urbanización de terrenos destinados a instalaciones de actividades productivas relevantes o de especial importancia y para la formación de polígonos industriales.

(38) La disposición transitoria quinta determina que sel Gobieno elaborard y remitirá a las Cortes un Proyecto de Bases del Plan Nacional...».

(39) El Plan Nacional de Ordenación, con arreglo al artículo $70^{\circ}$ de la reciente Ley del Suelo, debe contener... la determinación de las grandes directrices... (apartado 1); debe redactarse por... organismos públicos y privados, Entidades locales, con participación de la Organización Sindical... (capítulo 2), y su aprobación corresponde a las Cortes; su actualización y concordancia con los Planes de Desarrollo, al Gobierno, en la forma que dispongan las leyes que los aprueben (apartado 3).

(40) El artículo 7. de la Ley de Régimen del suelo y Ordenación urbana de 2 de mayo de 1975 describe el contenido del Plan Nacional, los protagonistas de su redacción, la iniciativa del Ministerio de la Vivienda, la aprobación mediante ley, pero la actualización y concordancia con los Planes de Desarrollo epodrás llevarse a cabo por el Gobierno; luego no es más que una posibilidad reglada por las.leyes aprobatorias de las mismas. 
rios y además de algún Ministro en concreto, dejamos este catálogo prometido, a juicio de cada uno, para evaluar el futuro con esta serie de tareas encomendadas, permitidas, obligadas, etc. Con una responsabilidad en general del Gobierno, en alguna ocasión del Consejo de Ministros, con participación de los Ministerios de la Presidencia, Gobernación, Vivienda, Justicia, Información y Turismo, etc., con la intervención del Consejo de Estado, con plazo y sin plazo, con refundiciones sobre determinadas normas concretas y otras veces sobre una materia, con armonizaciones, congruencias, puestas de acuerdo, adaptaciones, desarrollo, normas ejecutivas y acoplamientos orgánicos. La simple descripción del futuro previsto en las disposiciones finales y transitorias ofrecen un complicado panorama en que la tarea es ingente y perentoria, pues dadas las características y repercusiones de una nueva Ley del Suelo, aunque sólo fuera por su trascendencia social y el número de los afectados, evidentemente no es susceptible de trivialización.

La legislación delegada ha sido doctrinalmente examinada (41), no es el momento de examinar la forma utilizada en la reciente Ley del Suelo, donde se han manejado casi todos los procedimientos de derogación (42), sistemas de vigencia, modificaciones por contagio, etcétera.

Se quiere marcar especialmente el énfasis que la tarea de refundición no sólo supone la búsqueda de preceptos y su articulación sistemática en una norma congruente, hay también una labor de aarmonizar», palabra repetida en las disposiciones finales de

(41) Eduardo GARCtA DB ENTERRtA: Legislación delegada, potestad reglamentaria y control judicial, Madrid, Tecnos, 1970, vid. capítulo IV, aExamen dogmático de la delegación legislativa», págs. 79 y sigs., y en especial el apartado II del capítulo $V$, dentro de las especies de delegación», los textos refundidos. El contenido delegativo de la refundición y el efecto sustitutivo, págs. 130 y sigs.

(42) Tal vez el legislador de 1975 ha olvidado poner en práctica un criterio de derogación muy singular que utilizó la Ley 14/1970, de 4 de agosto, General de Educación y financiamiento de la reforma educativa, que en su disposición final cuarta dispone: 1. A partir de la publicación de la presente Ley, todas las disposiciones anteriores, cualquiera que fuese su rango, que venían regulando las materias objeto de la misma regirán únicamente, en cuanto fueran aplicables como normas de carácter reglamentario, hasta que vayan entrando en vigor las respectivas disposiciones que se dicten en ejercicio de esta Ley, en cuyo momento quedarán totalmente derogadas». El sistema de degradación normativa del rango de las disposiciones no ha sido utilizado de forma directa por la Ley del Suelo, si bien en algún supuesto ha dilatado la eficacia de sus preceptos (disposición final quinta, último párrafo), a que entren en vigor otras normas (la Ley de Bases del Estatuto de Régimen local), o interinamente son válidos y eficaces determinados artículos del texto de 1956 hasta que otra norma, ya en trance de discusión en las Cortes, se apruebe (disposición final quinta, párrafo primero). De alguna forma hay degradación si no de rango, si al menos en la eficacia y vigencia. 
la nueva Ley del Suelo, pero también aadaptar expresión también repetida en dicho texto legal, además aincorporar» a lo que se autoriza al Gobierno especialmente, aunque no se diga también «aclarar» y «regularizar». Si a ello añadimos las precisiones de un reglamento general ejecutivo, posibles reglamentos parciales $\mathrm{y}$, potencialmente, reglamentos independientes y delegados, la panorámica es muy rica en matices, y en el momento de realizarse en toda su extensión y con intensidad la riqueza y problemática, complejidad y actividad necesaria para cumplir las previsiones, para poner en marcha los mecanismos idóneos, nos va a ofrecer un extenso campo no sólo de digresión y elucubración doctrinal, sino de aplicación práctica y posible controversia judicial.

\section{EL PROBLEMA DE LA VIGENCIA Y APLICACION EN EL CONTEXTO INTERNO DE LA NUEVA LEY DEL SUELO}

Hemos enunciado, a grandes rasgos, la problemática que conlleva la aplicación de la nueva normativa en relación con las precisiones relativas a impactos que vienen desde fuera. Justo es evaluar ahora la validez interna de los preceptos en el texto reformado, donde se producen situaciones particulares que afectan a la validez de los preceptos contenidos en el ordenamiento urbano y régimen del suelo.

Las cuestiones pueden agruparse convencionalmente en las siguientes:

a) Las disposiciones contenidas en la Ley de 1956, que permanecen inalteradas, sensiblemente la mitad del texto, se encuentra, afectadas por la Ley reformadora y su aplicación, ya que su vigencia es indiscutible, pero ahora están modificadas por la armonización, adaptación necesaria no sólo al texto nuevo, a su redacción, sino incluso al espíritu innovador y reformador implantado en 1975. Hay una certidumbre, y es que la nueva Ley del Suelo responde a una filosofía distinta, y este hálito debe traspasar, como está previsto, al texto anterior (43).

(43) Cuando la disposición final segunda de la nueva Ley del Suelo dice, respecto del texto refundido, que ha de armonizar con lo dispuesto en esta Ley el contenido de todas las disposiciones refundidas, está expresamente refiriéndose a este tema. 
b) Disposiciones que van a ser derogadas y otras puestas en vigor como consecuencia de la aprobación de los otros cuerpos legales. El tema lo hemos citado y se refiere a los artículos 162 a 164 y 183 a 188 , que se sustituirán por las correspondientes bases de la Ley de Bases del Estatuto de Régimen local (44), e incluso la entrada en vigor de artículos (el 188 bis y ter) en una interinidad en cuanto a su eficacia. Las implicaciones son graves, pues las medidas de fomento a la edificación por parte de las Entidades locales quedan paralizadas sin conocer exactamente el momento de iniciarse su actuación, así como la posible afectación de beneficios a la gestión urbanística correspondiente (45).

Además, estos artículos se encuentran relacionados con todo el sistema establecido de nueva planta, quedando huérfano de esta filiación, descolgando sin esta implementación que supone un eficaz complemento.

c) Disposiciones que por remisión a otros cuerpos legales se realizan en éstos: Ley de Procedimiento administrativo, Expropiación forzosa, Contencioso-administrativo, etc., por enunciar las más caracterizadas.

d) Disposiciones reguladoras de normas urbanísticas típicas, como son los Planes Generales Municipales de Ordenación (46), pieza clave, concebidos como planes abiertos sin plazo de vigencia fijo, pero constantemente modificados, primero automáticamente en los plazos señalados en los mismos; segundo, cuando las circunstancias lo exigiesen por el Ministro de la Vivienda; tercero y cuarto, cuatrienalmente en principio por los Planes de Desarrollo; quinto, su posible revisión, previa la suspensión, de acuerdo con lo establecido en el artículo 22. El tema es trascendental para un juego de la eficacia y aplicación; en definitiva, vigencia de normas, sobre todo porque estas modificaciones no dan lugar a indemnización, al no estar recogidas en la modificación o revisión de planes del artículo 70.2, pero resulta que los planes parciales no podrán

(44) Supuestos contemplados en la disposición final quinta.

(45) El artículo 188 ter habla de los beneficios obtenidos en virtud de lo dispuesto en el mismo, dicho producto se afecta a la gestion urbanistica. Parece demasiado dilatar la entrada en vigor del precepto.

(46) Se regula la revisión en el artículo 37 de la nueva Ley de Régimen del suelo y Ordenación urbana. Sobre sus características y trascendencia, vid. el preámbulo de la Ley, apartado cuarto, párrafo segundo, en el que se habla de la concepción de la nueva Ley respecto a dichos planes. 
redactarse sin Plan general previo (47), y éste está sometido a todas las inclemencias enunciadas, que se trasladan con efectos de aceleración y gravedad acumulada.

e) Disposiciones en expectativa, latentes, tan importantes como son las competencias urbanísticas de las Entidades locales, ahora un tanto deterioradas, pendientes de una sucesiva serie de actos.

$\left.a^{\prime}\right)$ Aprobación de la Ley de Bases del Estatuto de Régimen local (actualmente en discusión en las Cortes).

$\left.b^{\prime}\right)$ Aprobación de un texto articulado de la Ley de Bases.

c') Aprobado y publicado el texto articulado de Régimen local, en un plazo de seis meses el Consejo de Ministros hace una nueva refundición, aunque no se exprese así (48), para incorporar nuevas normas sustantivas que han de afectar a disposiciones hoy vigentes, las que aparezcan en el texto refundido, y, en definitiva, podrá darse una contradicción o antinomia dentro del texto; si hay acomodación, adaptación, acuerdo de normas, ésta será una segunda refundición, como en otros supuestos específicos y previstos también, aunque no con tal énfasis como en este caso.

d') Se da por supuesta la existencia de un texto articulado de la Ley del Suelo. Circunstancia que podría no producirse, al menos hipotéticamente posible en estos momentos. Pues bien, toda la materia de competencias urbanísticas de las Entidades locales, protagonistas importantes en la aplicación, ejecución, dirección y gestión de la ordenación urbana y participantes del régimen del suelo, se encuentra actualmente mediatizada, existe, pero de forma ambigua, va a cambiar, pero se desconoce el cuantum, la extensión e intensidad de estos poderes locales son hipotéticos, incógnita que al despejarse debe afectar a todo el cuerpo legal. Por eso se estima que hay una vigencia definida, pero no definitiva, de todos aquellos preceptos de la Ley que regulen competencias urbanisticas o se relacionen con ellas.

(47) El artículo 10, 1, párrafo 2., dice taxativamente: *No podrán redactarse Planes parciales sin Plan general previo....

(48) A propuesta de los Ministros de la Gobernación y de la Vivienda y previo dictamen del Consejo de Estado se incorporará al texto refundido de la Ley del Suelo, en lo que prevé necesario, las competencias urbanísticas de las Entidades locales en la forma y ámbito que para cada una de ellas establezca la legislación del Régimen locals (disposición final cuarta). Esta incorporación supone una nueva refundición de segundo grado. Y no es tarea fácil, pues afecta a otras disposiciones ya incorporadas en el texto refundido de la Ley del Suelo. 
$\left.f^{\prime}\right)$ Los preceptos contenidos en la Ley del Suelo han de mantener, dentro de su contexto, unas tensiones obligadas por la forma, impacto histórico de producirse. La descripción de los acontecimientos nos lo confirma. En su día, con anticipación y visión, el fenómeno fue tratado desde la perspectiva legal, y la Ley de $12 \mathrm{de}$ mayo de 1956 irrumpe en el panorama normativo; sobre sus caracteres, trascendencia, inicial inaplicación, técnica empleada, etc., se ha comentado reiteradamente (49).

El tema del urbanismo en el Derecho español (50) se condensa en la Ley de 1956, ahora modificada, y el sistema para realizar esta revisión y reforma, como se verá más adelante, ofrece una panorámica de contrastes, pues conocida, divulgada y entroncada en la conciencia jurídico-social de nuestro país, propicia el desconcierto ante las múltiples interconexiones, reenvíos, adaptaciones, plazos de espera, incrustaciones normativas, promesas, encargos, imperativos, reestructuraciones. Todo ello necesario, pero de difícil armonización, que al conjugar la temática va a producir fricciones internas, a veces incongruencias, con frecuencia antinomias y desde luego necesidad de interpretación para su feliz aplicación.

Esta observación general de lo que internamente van a ser fricciones, falta de ajuste y coordinación, dificultad en la aplicación, es predicable con sus caracteres genéricos de ley en su contexto y dentro de sí, pues con frecuencia se olvida esta tarea, callada y a la vez obligada de compatibilización; pues un articulado se razona en una filosofía; una norma tiene su porqué y para qué justificativo; el tiempo opera de forma muy eficaz y solapada, a veces potencia o da voltaje e intensidad a las normas, otras veces actúa como deterioro, incluso hace a muchos preceptos obsoletos al incorporárseles este factor, En el supuesto estudiado, la Ley se

(49) Se ha dicho recientemente: $\alpha$ La Ley del Suelo española fue consecuencia de la rara conjunción de unos juristas y unos arquitectos geniales», GonZÁLZ-BERENGUER, artículo citado, pág. 14. Se precisan también los nombres de BaLlBE, GaRCfa HERNANDEZ y Bigador. Es BaLlBe, en las Jornadas Municipalistas en las Islas Canarias, bajo el tema *Comentarios de la Ley del Suelo» (conferencia XI), el que hace un análisis responsable de lo que la Ley representa, vid. págs. 5 y sigs. de la separata de su conferencia en las citadas Jornadas.

(50) Vid. Problemas politicos de la Vida local. Colección aEstudios de Administración, a cargo de Fernando Garrido Falla, Instituto de Estudios Políticos, Madrid, 1962, tomo II. En especial la conclusión aUrbanismo y suelo en el Derecho español», Director José Antonio Garcta-Trevijano Fos, Peñíscola, 30 de agosto de 1961. En 25 conclusiones se analizan todas las cuestiones pendientes en aquellos momentos y necesidades de solución. Con gran anticipación se sitúan determinadas cuestiones trascendentales, vid. las conclusiones $20,21,23,24$ y 25 sobre la tarea a realizar. 
piensa modificar en 1970 , se gesta la modificación y se publica el Proyecto en 1972, que permanece en las Cortes hasta 1975, año en que se resucita, discute y aprueba. La razón del porqué de la reforma se explica por el Gobierno (51), que aduce razones para la misma. El tema es espinoso, prueba de ello ha sido el laborioso proceso de gestación; sin embargo se discute en pocos meses y se aprueba. Pero a nuestros efectos de posible contraste interno, y a veces de inadecuación, es que el sistema legal de normación del suelo, nadie discute es muy técnico, debe contar con una gran coherencia intima, pues arriesga, al fallar alguna pieza del mecanismo, se produzca un efecto respecto al todo, resentido por este fallo, lo cual se corresponde con un deterioro del conjunto. Hay, pues, una materia delicada y perfecta, ya en 1956 y ahora el tema sigue respondiendo a los mismos esquemas, por tanto es presumible el que se den las distorsiones enunciadas.

\section{UN GRAFICO DE LA SITUACION: DEDUCCIONES DE GRAFICAR LA VIGENCIA DE LA NUEVA LEY DEL SUELO}

Utilizar grafos, grafiar, hacer un gráfico, graficar, en definitiva, un diagrama de una situación no es procedimiento al uso ni convenido en tareas como la emprendida, vocacionalmente abocadas a esclarecer y no complicar la ya compleja temática.

Al comenzar esta tarea, en definitiva, examen de la viabilidad de una ley, cuyo inmediato antecedente había soportado, a manera de cuarentena, años de inaplicación (52) no ya como en la actualidad, a causa de un complejo mecanismo de adaptación de una ley reformada, sino por otros motivos, su perfección técnica, su anticipación, su novedad, pues, surgía de la nada, etc.

Con esta vocación del trabajo presentado, de servir, en momentos de cierta perplejidad, de orientación en cuanto a la posible

(51) El porqué de una reforma, Servicio de Publicaciones del Ministerio de la Vivienda, Madrid, noviembre de 1972.

(52) El tema de la inaplicación de la Ley del Suelo ha sido reiteradas veces denunciado por la doctrina; sobre su recepción y aplicación, cfr. «La política urbanístican, Romay Beccarta, en aEl Estado y la políticas, dentro del estudio la España de los años setenta, vol. III, tomo II, Madrid, 1974. Estudio aMoneda y Créditos, en especial el punto 2.6, sobre el tema de la dificultad de su aplicación, por sus excelentes niveles técnicos, necesitados de un esfuerzo para adaptar las conciencias de propietarios, administradores, funcionarios, arquitectos, juristas y jueces, vid. pág. 775, op. cit. 
aplicación, como instrumento didáctico, nos hemos servido de un planning, desde otra perspectiva un pert time, a base de plasmar gráficamente las disposiciones finales del original texto de reforma de la Ley sobre Régimen del suelo y Ordenación urbana. Con estas catorce pautas iniciamos la investigación $\mathrm{y}$, al ir superponiendo tareas, plazos al Gobierno, intervención de diversos Ministerios, dictámenes del Consejo de Estado y otras actividades, dispusimos casi intuitivamente, pues no se tenía tal intención en la gestación de este trabajo de ofrecer una planimetría de la cuestión.

Dificultad grande supone armonizar una serie de trazos, representar plazos, simbolizar vinculaciones y discrecionalidades, señalar opciones y más aún si se tiene en cuenta que muchas de estas actividades dependen jurídicamente de otra expectativa, actualmente en trance de discusión, la nueva Ley de Bases del Estatuto de Régimen local (53).

La situación del urbanismo en España a -mediados de la década de los setenta, va a ser necesariamente decantada con arreglo al siguiente esquema:

El cuadro no necesita más explicación que la aportada en nota sobre la simbología. Como complemento diremos que las tareas del Gobierno se realizan o bien por el Ministerio de la Vivienda (V) o de la Gobernación (G), Información y Turismo (I T), Justicia (J).

En lo que sí creemos necesaria la explicación es en la concepción del mismo, con una triple división horizontal, que separa tres cuerpos de actividades delimitadas por trazos discontinuos. En la parte superior hay una labor a realizar por el Gobierno respecto a

(53) Gracias a la colaboración del Jefe de Sección de Infraestructura, Tráfico y Servicios Urbanos, del Centro de Estudios Urbanos, del Instituto de Estudios de Administración Local, lo que era hipotético se ha hecho realidad: graficar la situación. Las dificultades sería necesario haberlas presentado en su primera redacción para comprender el mérito del Ingeniero de Caminos Ricardo Santos Dfez, que con comprensión y benevolencia ha logrado esquematizar y plasmar gráficamente la nueva Ley del Suelo en el relevante aspecto de su vigencia. El laberinto expresionista con el que iniciamos nuestra tarea, eficazmente demuestra el necesario tratamiento interdisciplinar de los temas urbanísticos, supuesto concreto. Perseguiamos un objetivo: «pinchar gráficamente un esquema en la pared de cualquier despacho, laboratorio de nuestras ideas, para conseguir un testigo de quehaceres en un futuro perentorio, con plazos, con términos, transido de tiempo y espacio, como categorías determinantes. Si con esta colaboración no se ha conseguido, reclamo la responsabilidad, pues desde mi óptica de investigar el Derecho que se vive a través del que se escribe, la colaboración del excelente profesional para mí ha sido decisiva, me ha abierto por demás un campo, a efectos de muestra, con amplias posibilidades didácticas, disciplinar mediante grafos cuestiones que con frecuencia se escapan en exposiciones, por muy bien esquematizadas y ordenadas que se presenten. 
REVL-1975, núm. 186. CARRASCO CANALS, CARLOS. UN PROBLEMA DE VIGENCIA Y APLICACI...

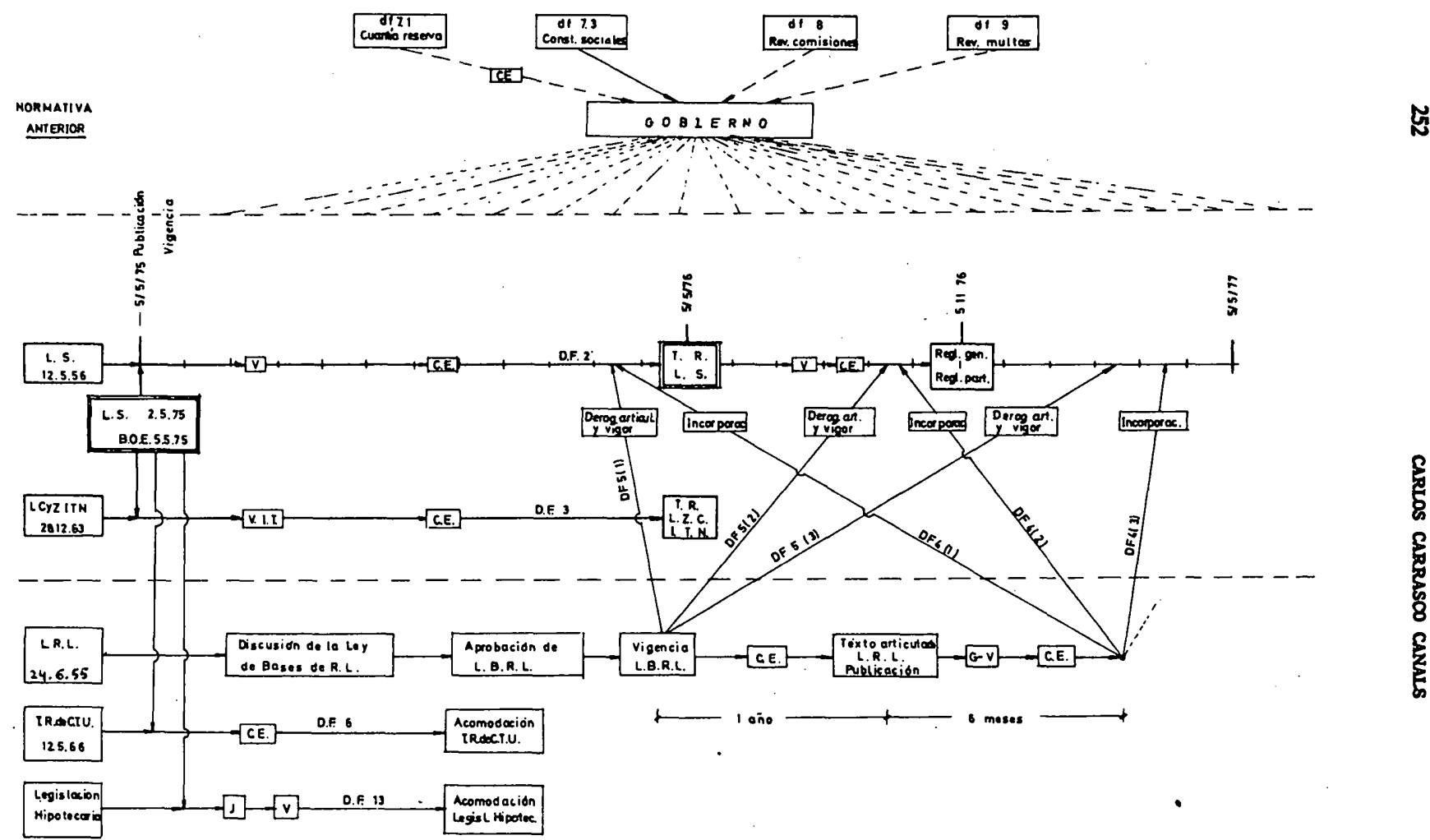

NOTA: Los plazos marcados son máximos.

\section{Simbologia y abreviaturas:}

V : Gobierno, a propuesta del Ministerio de la Vivienda.

C. E. : Previo informe del Consejo de Estado.
D. F.: df: Disposición final de la Ley del Suelo.

L. S.: Ley del Suelo.

T. R. L. S.: Texto refundido Ley del Suelo

Regl. gral.: Reglamento general.

Regl. part.: Reglamentos particulares.

L. C. y Z. I. T. N.: Ley de Centros y Zonas de interés turístico nacional.

T. R. L. C. y Z. I. T. N.: Texto refundido de Ley de Centros y Zonas de interés turístico nacional.

L. R. L.: Ley de Régimen local.

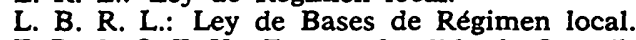

T. R. de C. T. U.: Texto refundido de Contribución Territorial y Urbana 
una normativa anterior, a una situación legalmente estatuida en la actualidad.

El cuerpo central es el de la Ley del Suelo y sus incidencias, como lo es, en paralelo, la refundición de la Ley de Centros y Zonas de interés turístico nacional.

El espacio inferior, delimitado por las paralelas expresadas en líneas discontinuas, nos ejemplifica la Ley de Régimen local, sus previsibles desarrollos y en algún supuesto las previsiones, en relación con plazos, del Proyecto de Ley de Bases en discusión. Otros temas de acomodación (la de la Contribución Territorial Urbana y la legislación hipotecaria) finalizan la exposición, que tiene un evidente efecto de demostración y muestra de forma bastante cla$\mathrm{ra}$, cual es la trayectoria y posible realidad en un futuro inmediato y en el mediato, cuando la Ley de Régimen local sea realidad.

Un condicionante en la actuación mediante esta singular representación ha sido evitar el fárrago y la complejidad para plasmar sencillamente lo que era heterogéneo y en principio farragoso. Lograr esta quintaesencia nos obliga a prescindir de representar las disposiciones transitorias (54), pues, aunque no querido esto, complicaría de forma clara la exposición. Además, estos mandatos contenidos en la parte "transitoria» son más inteligibles, aunque se solapan con los encargos de las disposiciones finales explicitadas. En definitiva, se señala el quehacer, el modus operandi hasta la plena vigencia, desarrollo y adaptaciones en la nueva Ley de Régimen del suelo y Ordenación urbana.

Importante y natural corolario es ahora resaltar, además de los aspectos concretamente aludidos, las posibles deducciones provinientes de una reformación, reordenación del tema.

1. El mecanismo de "reforma», muy próximo al de ofrecer un texto «revisado» (55), constituye de por sí una modificación, pues se

(54) Como instrumento de trabajo, también hemos representado gráficamente las cinco disposiciones transitorias de la nueva Ley del Suelo, que contiene preceptos tan importantes como el de remitir por el Gobierno a las Cortes, en el plazo de un año, el Proyecto de Bases del Plan Nacional de Ordenación (trans. quinta). El gráfico resultante de todas las tareas encomendadas, relacionándose y confluyendo con la actividad determinada por las disposiciones finales, hacen una maraña aparentemente indescifrable lo que se preteiidía fuese representación clara. Ofrecer dos cuadros era trivial, pues cualquier interesado, como instrumento de trabajo, puede para su uso confeccionar una herramienta de esta naturaleza, y si le sirve de muestra y ejemplo, se le ofrece la del texto de este artículo.

(55) En realidad, los textos revisados son a manera de textos refundidos. Es el caso de la reforma del Código penal, aprobado por Decreto de 28 de marzo de 1963, que incluye artículos sin contenido para evitar un cambio de numeración, pero todo ello para mantener inalterable la redacción articulada y como conse- 
insertan cambios trascendentales en el sistema y afectan a un sector de actividad e interesados muy importante, con repercusiones sociales, económicas e incluso políticas que exigen claridad en la temática como presupuesto y en la aplicación como consecuencia. La aclaración en cuestiones tan transidas de criterios técnicos como ocurre en urbanismo, es tarea difícil y arriesgada (56); se estima al respecto que la nueva Ley reformadora no es una aportación de técnica más depurada ni de aplicación más fácil que en el anterior supuesto (57) de 1956.

2. Sobre los problemas que la legislación delegada plantea no parece oportuno incidir; ahora bien, lo que es claro y palmariamente está patente en este supuesto concreto, es que determinados encargos al Gobierno pueden actuar indiscriminadamente si no se cumplen los requisitos formales que garantizan que un Decreto legislativo sea tal en puridad. Delegar en un órgano, el Gobierno generalmente, una materia concreta, la urbanística, y régimen jurídico del suelo y en un plazo. Pero con frecuencia, como se ha insinuado, se hacen encargos genéricos que habilitan al Gobierno, o en su caso al Consejo de Ministros, para incorporar al texto refundido de la Ley del Suelo las competencias urbanísticas de las

cuencia de la provisionalidad del texto. Algo similar ocurre ahora con la nueva Ley del Suelo, necesitada de incorporaciones, adaptaciones, derogaciones, desarrollos pendientes de aprobaciones de otros textos legales en sus más diversas formulaciones (Régimen local), en cuanto Ley de Bases y texto articulado (incluyo desarrollo reglamentario) o bien refundición de normas anteriores (Ley de Centros y Zona de interés túístico nacional) y todas aquellas otras manifestaciones normativas ya aludidas. Se puede decir, pues, que tenemos un texto revisado más que reformado en razón a su provisionalidad, siendo presumible en su día, tiempo tasado en plazos máximos, se pueda contar con una redacción definitiva que propicie un tema importante y no siempre lo suficientemente destacado como es el de la seguridad jurídica. No queremos insistir más sobre este aspecto, pero debe excitar a todos para que cuanto antes ésta se realice totalmente, ofreciéndose una plataforma legal para desarrollar la tarea urbanística en condiciones de la mayor seguridad a efectos de aplicación de un régimen jurídico concreto y delimitado.

(56) Uno de los responsables y promotores de la Ley del Suelo de 1956 nos explica (vid. Pedro BIDAGor LASARTE: «Situación del urbanismo en España, 1939. 1967„, Revista de Derecho Urbanistico, núm. 4) cómo se realizó esta tarea entre los años 1949-1956 y el intento depurador del contenido, sistema y forma de la Ley, que no se refería sólo al suelo, no concluyó en un estatuto del régimen del suelo, sino además de la ordenación urbanística de las ciudades. Constituye en realidad un código urbanístico que no soslaya los problemas del suelo, sino que los incardina en este tratamiento unitario del tema.

(57) Buen ejemplo de ello es el artículo 68 del nuevo texto de la Ley del Suelo, ininteligible por ahora, frente al anterior artículo 68 de la Ley de 1956, donde se podía cifrar perfectamente el aprovechamiento medio; actualmente, y por juego del artículo $68,2, a)$, el aprovechamiento medio de la totalidad del suelo urbanizable programado y el de cada sector no parece posible de fijación, pues no hay un criterio susceptible de someter a una métrica necesaria para realizar esta tarea. 
Entidades locales en la forma y ámbito que para cada una de ellas establezca la legislación de Régimen local (58). Por ahora disponemos sólo del Proyecto de Ley de Régimen local, por tanto no parece correcto aventurar los posibles hipotéticos, aunque previsibles, acontecimientos (59).

Toda la problemática imaginable se puede trasladar a las cuestiones puntuales que la nueva Ley del Suelo puede plantear en lo relativo al específico tema de la delegación legislativa. No es el momento de penetrar en tan rica problemática (60), simplemente su alusión como llamada de atención, alerta que en su día ha de funcionar.

3. Otro aspecto que sorprende y es deducción en esta forma de hacer, es el que se presenta cuando la nueva Ley del Suelo deba «entender» sustituidos los artículos 162 a 164 y 183 a 188, tema al que nos hemos referido. La pregunta consiguiente: ¿Habrá que sustituir los artículos, quién lo hace? No hay una encomienda determinada (61), pero, además de hacer una congrua entre artículos y bases, no es tarea llana ni sencilla; además podría ocurrir que en la discusión de las bases de Régimen local no quedase el tema adecuado, aunque previsiblemente se tenga en cuenta esta previsión contenida en la Ley del Suelo para redactar, a manera de artículos, las bases que han de incorporarse posiblemente ya a un texto refundido o si no al articulado de 1956, con una incrustación típica por sustitución. A esta complejidad se une con efecto multiplicador la entrada en vigor simultánea de los artículos 188 bis y ter, que en la actualidad penden de la entrada en vigor de la Ley de Bases para realizarse en el interesante tema de su eficacia,

(58) La disposición final cuarta de la nueva Ley del Suelo así lo establece. En la representación gráfica, después del texto articulado, en una línea que prolonga la del presumible desarrollo de la Ley de Régimen local, se sitúan las tres posibilidades de incorporación. Hubiese sido más correcto situar gráficamente esta representación en la parte superior, pero por claridad representativa se ha grafiado de esta manera en el plazo de seis meses después del año previsto en la disposición final primera del Proyecto de Ley de Bases del Estatuto de Régimen local.

(59) La base octava del Proyecto, en su punto $3 .^{\circ}$, habla de competencia municipal en materia de urbanismo y vivienda, y la 17.4 al finar la capacidad de las Entidades provinciales alude las relativas a materia urbanística, cuando las competencias exceden de las posibilidades financieras y técnicas de cada Municipio.

(60) Vid. Eduardo GARCtA DB ENTERRta: Legislación delegada, op. cit., donde hace un examen dogmático de la delegación legislativa, vid. págs. 79 y sigs. Un buen tema susceptible de especulación y contraste empírico serfa el de la nueva Ley del Suelo.

(61) La disposición final quinta de la Ley de 2 de mayo de 1975 dice se «entenderán sustituidos», pero no se encarga a nadie de hacer esta sustitución; parece funcionará automáticamente la previsión. 
versus la vigencia de los mismos. Aquí se plantea otra vez la repetida cuestión de la congruencia para que estos artículos se ordenen de forma armónica con los sustituidos por bases, pues también podrían producirse inadecuaciones, tensiones o fricciones.

4. Un examen panorámico completo nos conduce a examinar la mecánica de la nueva Ley de Bases, Estatuto del Régimen local, que permite por vía negativa, "falta de incompatibilidad", incorporar al texto articulado de la Ley de Régimen local los preceptos de cualquier naturaleza que afecten a los Municipios y Provincias. Todos los temas del suelo y ordenación urbana, mucho tienen que ver con este aspecto (62).

Lo mismo ocurre con el texto refundido de la Ley de 28 de diciembre de 1963, sobre Centros y Zonas de interés turístico nacional, pues hay que realizar una adaptación de este texto refur.dido al nuevo régimen del suelo, ¿pero en qué versión? Ya existe un texto reformado, podría esperarse al texto refundido de la Ley del Suelo ¿en su primera o segunda refundición posible? Además, como va a sufrir una serie de adaptaciones, incrustaciones y modificaciones tasadas ya y previstas, como gráficamente se ha mostrado ¿en qué medida influirá la trayectoria del régimen del suelo y ordenación urbana en la del texto refundido de la Ley de Centros y Zonas turísticas y en qué momento? Las preguntas se podrían multiplicar, y lo evidente es que hay como un contagio que impregna todo este proceso $y$, por acumulación, una aceleración continua y progresiva que problematiza a límites no sospechados.

Hemos ejemplificado dos importantes regímenes normativos, el del Régimen local y del Turismo en un aspecto sectorial, pero esto es predicable respecto de los demás, que han sido sido expuestos gráficamente.

Razones evidentes de parquedad nos instan a sugerir sea el propio estudioso de estos temas el que problematice las cuestiones, reiteradas a veces por su contraste, otras casi ni siquiera insinuadas, pues necesitan de un rodaje previo, resaltando siempre lo significativo de un efecto de demostración, como graficar unas previsiones, encargo heterogéneo y complejo a la vez que comprometido, en el ánimo de cooperar a una tarea siempre inacabada, pero esencial, como el urbanismo.

(62) Disposición final primera, 2, del Proyecto de Ley de Bases del Estatuto del Régimen local, vid. edic. I. E. A. L., Madrid, 1974. pág. 135. 